\title{
The role of cytokine gene polymorphism in the development of acute myocardial infarction
}

\author{
Ye. V. Sid' \\ State Institute "Zaporizhzhia Medical Academy of Postgraduate Education of Ministry of Health of Ukraine"
}

Key words: inflammation, myocardial ischemia, myocardial infarction, gene polymorphism, cytokines.

\section{Zaporozhye} medical journal 2017; 19 (5), 680-683

DOI:

10.14739/2310-1210 2017.5.110234

E-mail: sidzenek@gmail.com
The continuous growth of cardiovascular diseases is one of the important challenges facing the modern medicine. They are the primary cause of death both in developed countries and in Ukraine in particular.

The aim of the study is to perform analysis of modern literary sources related to the role of cytokine gene polymorphism in the development of acute myocardial infarction.

The basis for the search for candidate genes was study of individual characteristics and identifying genetic polymorphisms that increase the risk of triggering mechanisms of atherosclerotic lesions of the coronary vessels and the consequent acute myocardial infarction development. Cytokine genes feature a very high level of polymorphisms. The obtained results of the study are quite contradictory, in addition there is no consensus on their application. One of these candidate genes is the gene encoding interleukin-6 production. This is one of the proinflammatory cytokines, elevated levels of which are associated with the development and course of coronary heart disease, as well as with the processes of the atherosclerotic plaque destabilization. Polymorphic marker in interleukin-6 (-174-G/C) gene promoter is associated with IL-6 gene expression level and the level of Interleukin-6 in plasma, and can affect the course of ischemic heart disease. The tumor necrosis factor- $\alpha$ is a multifunctional proinflammatory cytokine which is produced mainly by monocytes and macrophages. Concentration of tumor necrosis factor- $\alpha$ in blood plasma is constantly increased in patients after acute myocardial infarction with an increased risk of recurrent coronary events. These data support the hypothesis that stable patients are at risk of constant inflammatory instability. Increased production of tumor necrosis factor- $\alpha$ is considered an important cause of destabilization of atherosclerotic plaques. The gene cluster of tumor necrosis factor- $\alpha$ is within the region of class III genes of highly polymorphic major histocompatibility complex, located on human chromosome 6 at the position 6p21.1-21.3. Another candidate gene encodes interleukin-10, being an anti-inflammatory cytokine is an inhibitor of inflammation located on chromosome 1 at the position 1q31-q32. The research identified a number of IL-10 gene polymorphisms at positions $-592,-627,-1082$.

Conclusions. Analysis of the above literature allows us to make a conclusion that: first, the concentration of cytokines depends on the genetic characteristics of an individual; secondly, cytokine gene polymorphism may be of importance in regard to the course of coronary heart disease.

\section{Киючові слова:} запальна відповіАь, ішемічна хвороба серця, гострий інфаркт міокарда, поліморфізм генів, цитокіни.

Запорізький медичний журнал. - 2017. T. 19, № 5(104). C. $680-683$

\section{Значення поліморфізму генів цитокінів у розвитку гострого інфаркту міокарда \\ €. В. Сідь}

Одна з важливих проблем сучасної медицини - безперервне зростання серцево-судинних захворювань, що є провідною причиною смерті як у розвинених країнах світу, так і в Україні зокрема.

Мета роботи - проаналізувати сучасні наукові літературні джерела щодо значення поліморфізму генів цитокінів у розвитку гострого інфаркту міокарда.

Вивчення індивідуальних особливостей людини та виявлення генетичних поліморфізмів, що збільшують ризик запуску механізмів атеросклеротичного ураження коронарних судин та, як наслідок, розвиток гострого інфраркту міокарда, стало основою початку пошуку генів-кандидатів. Гени цитокінів мають дуже високий ступінь поліморфізму. Результати досліджень доволі суперечливі. Крім того, відсутній консенсус щодо їхнього застосування. Один із таких генів-кандидатів - ген, що кодує продукцію інтрелейкіна-6. Це - один із прозапальних цитокінів, підвищені рівні якого пов'язують із розвитком і перебігом ішемічної хвороби серця, а також із процесами дестабілізації атеросклеротичної бляшки. Поліморфний маркер у промоторі гена IЛ-6 (-174-G/C) асоційований із рівнем експресії гена ІЛ-6 і з рівнем інтерлейкіна-6 у плазмі, що може впливати на перебіг ішемічної хвороби серця. Фактор некрозу пухлин- $\alpha$ - це багатофункціональний прозапальний цитокін, що утворюється здебільшого моноцитами та макрофагами. Концентрація у плазмі крові фрактора некрозу пухлин-а постійно підвищена у хворих після гострого інфраркту міокарда з підвищеним ризиком повторних коронарних подій. Ці дані підтримують гіпотезу, що постійна запальна нестабільність присутня серед стабільних пацієнтів. Підвищення продукції фрактора некрозу пухлин-а розглядається як важлива причина дестабілізації атеросклеротичної бляшки. Ген кластера фактора некрозу пухлин-а перебуває в межах регіону генів III класу високополіморфнного головного комплексу гістосумісності, розташований на людській 6 хромосомі в позиції 6p21.1-21.3. Інший ген-кандидат кодує інтерлейкін-10: протизапальний цитокін є інгібітором запалення, розташований на 1 хромосомі в позиції 1q31-q32. У дослідженнях виявлений поліморфізм гена інтерлейкін-10 у позиціях -592, -627, -1082.

Висновки. Аналіз наукової літератури показує: концентрація цитокінів залежить від генетичних особливостей індивіда; поліморфрізм генів цитокінів може мати значення щодо перебігу ішемічної хвороби серця.

\section{Значение полиморфизма генов цитокинов в развитии острого инфаркта миокарда}

\section{Е. В. Сидь}

Одна из важных проблем современной медицины - непрерывный рост сердечно-сосудистых заболеваний, которые являются ведущей причиной смерти как в развитых странах мира, так и в Украине в частности. 
Цель работы - проанализировать современные научные литературные источники о роли полиморфизма генов цитокинов в развитии острого инфаркта миокарда. Изучение индивидуальных особенностей человека и выявление генетических полиморфизмов, увеличивающих риск запуска механизмов атеросклеротического поражения коронарных сосудов и, как следствие, развитие острого инфаркта миокарда, стало основой начала поиска генов-кандидатов. Гены цитокинов имеют очень высокую степень полиморфизма. Результаты исследований достаточно противоречивы, кроме того отсутствует консенсус относительно их применения. Один из таких генов-кандидатов - ген, кодирующий продукцию интрелейкина-6. Это - один из провоспалительных цитокинов, повышенные уровни которого связывают с развитием и течением ишемической болезни сердца, а также с процессами дестабилизации атеросклеротической бляшки. Полиморфный маркер в промоторе гена ИЛ-6 (-174-G/C) ассоциирован с уровнем экспрессии гена ИЛ-6 и уровнем интерлейкина-6 в плазме, что может влиять на течение ишемической болезни сердца. Фактор некроза опухолей-а - это многофункциональный провоспалительный цитокин, образующийся в основном моноцитами и макрофагами. Концентрации в плазме крови фрактора некроза опухолей- $а$ постоянно повышена у больных после острого инфаркта миокарда с повышенным риском повторных коронарных событий. Эти данные поддерживают гипотезу, что постоянная воспалительная нестабильность присутствует среди стабильных пациентов. Повышение продукции фактора некроза опухолей-а рассматривается как важная причина дестабилизации атеросклеротической бляшки. Ген кластера фактора некроза опухолей- $\alpha$ находится в пределах региона генов III класса высокополиморфного главного комплекса гистосовместимости, расположен на человеческой 6 хромосоме в позиции 6p21.1-21.3. Другой ген-кандидат кодирует интерлейкин-10 - противовоспалительный цитокин является ингибитором воспаления, расположен на 1 хромосоме в позиции 1q31-q32. В исследованиях выявлен ряд полиморфизмов гена интерлейкин-10 в позициях $-592,-627,-1082$.

Выводы. Анализ научной литературы показывает: концентрация цитокинов зависит от генетических особенностей индивида; полиморфизм генов цитокинов может иметь значение для течения ишемической болезни сердца.

\section{Actuality}

The continuous growth of cardiovascular diseases (CVD) is one of the important challenges facing the modern medicine. They are the primary cause of death both in developed countries and in Ukraine in particular. Coronary heart disease $(\mathrm{CHD})$ as a chronic disease with periods of its exacerbation is one of the most serious health and social problems, since its clinical form, in particular acute myocardial infarction (AMI), has a high mortality rate [1].

Identification of atherosclerotic plaque instability early markers has a grate practical importance for cardiovascular complications risk stratification. Therefore, in recent years the markers of systemic inflammatory response syndrome are being intensively studied as predictors of CHD destabilization. According to the research findings, elevated levels of proinflammatory cytokines are evident not only in patients with acute coronary syndrome (ACS), but also in patients with stable form of $\mathrm{CHD}$ - exertional angina [2].

It is known that hereditary factors play a key role in the development of $\mathrm{CHD}$. The identification of genetic markers of $\mathrm{CHD}$ destabilization risk may be useful for solving the problem of CVD prevention, therefore the study of molecular-genetic characteristics of an individual is relevant with modern trend in medicine. Hence, the scientists were focused on study of genetic polymorphisms associated with the pathogenesis of this disease acute condition in recent years [3].

Recent studies show the important role of cytokines in the initiation and progression of atherosclerotic process. However, the study regarding the significance of cytokine gene polymorphism in the development of AMI is represented by a small number of works (papers, articles). Given the high social significance of AMI complications, the prevention of this disease is one of the urgent problems facing the modern cardiology [4].

The aim of the study is to perform analysis of modern literary sources related to the role of cytokine gene polymorphism in the development of acute myocardial infarction.

\section{Review of literature}

The basis for the search for candidate genes was the study of individual characteristics and identifying genetic poly- morphisms that increase the risk of triggering mechanisms of the coronary vessels atherosclerotic lesions and the consequent AMI development. The obtained results of the study are quite contradictory, in addition there is no consensus on their application. Furthermore, there exist ethnic differences of gene polymorphism which determines the relevance of such studies in Ukrainian population [5,6].

Cytokine genes feature a very high level of polymorphisms, at that the number of their sites can reach dozens. These fragments of DNA contain the determinants of regulative factors, and they are the ones that determine the intensity with which the cells produce cytokine molecules. The presence of gene polymorphism in promoting sites provides a variety of individuals according to the degree of their development during antigenic stimulation, that is, the formation of the inflammatory response $[7,8]$.

The process of the inflammatory response formation is accompanied by the production both of a fairly wide range of cytokines and other mediators that form the regulatory system. It contains elements which have a synergistic or antagonistic effect, so affecting any pathological process in the body and variations in its progress and results. Several studies show that the haemostatic system plays an important role in the pathogenesis of atherosclerosis and the formation of exacerbations of CHD. Of interest is the choice of candidate genes which products are involved in the development of inflammatory processes and associated with increased risk of adverse outcomes in $\mathrm{CHD}$ [9].

One of these candidate genes is the gene encoding interleukin-6 (IL-6) production. This is one of the proinflammatory cytokines, elevated levels of which are associated with the development and course of $\mathrm{CHD}$, as well as with the processes of the atherosclerotic plaque destabilization and the subsequent development of acute coronary syndrome (ACS) $[10,11]$.

Functional polymorphic marker in IL-6 (-174-G/C) gene promoter is associated with IL- 6 gene expression level and the level of Interleukin- 6 in plasma, and can affect the course of ischemic heart disease after suffering ACS. Thus, in the study of $\mathrm{S}$. Aker et al. the CC genotype was significantly associated with the violation of patients survival, being an independent risk factor for death (HR 3.58, $95 \%$ Cl 1.41-9.07, p < 0.01) according to the results of the multivariate analysis [12].
Ключевые слова: воспалительный ответ, ишемическая болезнь сераца, острый инфаркт миокараа, полиморфизм генов, цитокины.

Запорожский медицинский журнал. - 2017. T. 19, № 5(104). C. $680-683$ 
In another study conducted by M. P. Sie et al., the association of 174-G/C promoter polymorphism with the level of Interleukin-6 and C-reactive protein and arterial stiffness was studied. According to the study's findings, it was concluded that 174-G/C IL-6 gene polymorphism was associated with increased stiffness of arteries. Arterial stiffness which generally increases with age is a predictor of cardiovascular disease [13]

In their study, A.V. Shevchenko et al. studied the relationship of IL-6 (-174 G/C) gene polymorphism with classic risk factors in patients who have suffered from acute myocardial infarction. It was revealed, that the frequency of -174 GG genotype in the group of patients with AMI in present history was lower as compared to healthy people. The authors concluded that the analysed promotor region polymorphism of IL- 6 gene can be considered as an additional marker of predisposition to vascular disorders development [14].

The tumor necrosis factor- $\alpha$ (TNF- $\alpha$ ) is a peptide with the molecular weight of $17 \mathrm{kDa}$ which was discovered in the serum of patients with malignant neoplasms. This multifunctional proinflammatory cytokine is produced mainly by monocytes and macrophages [15].

Concentration of TNF- $\alpha$ in blood plasma is constantly increased in patients after AMI with an increased risk of recurrent coronary events. These data support the hypothesis that stable patients are at risk of constant inflammatory instability. Increased production of TNF- $\alpha$ is considered an important cause of destabilization of atherosclerotic plaques $[10,16]$.

The gene cluster of tumor necrosis factor- $\alpha$ is within the region of class III genes of highly polymorphic major histocompatibility complex, located on human chromosome 6 at the position $6 p 21.1-21.3$ between the lymphotoxin- $\alpha$ and lymphotoxin- $\beta$ genes. Despite the fact that more than 30 polymorphisms of TNF- $\alpha$ gene are known, the greatest interest of researchers was excited by the substitution at the positions $-238,-308,-863$ [17]

Given the variety of TNF- $\alpha$ effects, the studies of gene polymorphism at the position G-308A were carried out for various diseases. However, the data obtained in regard to the association of allele -308AA with a predisposition to $\mathrm{CHD}$ are ambiguous. According to the findings of some researchers, the replacement of the allelic variant by the mutant one is associated with CVD, according to other data there is no association with CVD [18].

R. Autonicelli et al. in their study stated association of $-308 \mathrm{~A}$ polymorphism with the development of AMI. The obtained results showed significant association between -308 TNF- $\alpha$ polymorphism and the occurrence of STEMI [19].

While Belgian scientists headed by A. Appoloni when examining groups of patients with AMI revealed that the mortality rate of cardiogenic shock was lower in carriers of the $-308 \mathrm{~A}$ allele variant. Thus the researchers arrived at the conclusion that it should be reasonable to determine the genotype of patients in order to predict the course of disease and to timely correct the administered therapy [20].

Australian scientists X. L. Wang and J. Oosterhof studied G-308 polymorphism associated with the level of extracellular superoxide dismutase. The research findings showed a positive and significant relationship between TNF- $\alpha$ gene polymorphism and levels of extracellular superoxide dismutase and homocysteine that are associated with clinical activity as oxidative stress in relation to atherogenesis. However, G-308 polymorphism is not directly associated with the occurrence and severity of atherosclerosis confirmed by angiography [21].
A group of researchers represented by T. Keso et al. have not found any tendency to atherosclerosis in the analysis of TNF-a gene polymorphism at the position -308. They have found no differences in coronary stenosis and the incidence of old or recent myocardial infarction or coronary thrombosis in men with different genotype status in the locus of control [22].

Thus, identification of TNF- $\alpha$ gene polymorphism at G-308A position may be useful for patients with AMI. However, the ambiguity and inconsistency of the research findings require further scientific inquiry.

Another candidate gene encodes interleukin-10 (IL10 ), being an anti-inflammatory cytokine with the molecular weight of $36 \mathrm{kDa}$, is an inhibitor of inflammation located on chromosome 1 at 1q31-q32 position. IL-10 gene encodes 178 amino acids of protein formed as a result of 18 amino acids catabolism [23].

The research identified a number of IL-10 gene polymorphisms at 592, $-627,-1082$ positions. The G-1082A polymorphic marker of IL-10 gene according to the studies is associated with the level of interleukin-10 production and can be associated with an increase in risk of $\mathrm{CHD}$ development $[24,25]$.

Genetic variation in G-1082A gene promoter (-4259AG, $-1082 \mathrm{GA},-592 \mathrm{CA},-2849 \mathrm{GA}$ ) and the risk of coronary and cerebrovascular events were studied within the framework of PROSPER (PROspective Study of Pravastatin in the Elderly at Risk). The researchers discovered a significant relationship between -592A polymorphism and the risk of coronary events. According to the findings of the study, S. Trompet et al. drew the conclusion that not only proinflammatory processes contribute to atherosclerosis, at that anti-inflammatory cytokines may also play an important role [26].

Reduced synthesis of IL-10 leads to a more pronounced inflammatory response that may increase the risk of ischemic heart disease destabilization. According to the results of their study, a group of scientists represented by A. Mälarstig et al. drew the conclusion that IL-10 reflects a proinflammatory state of patients with ACS and assumed that IL-10 is an effective biomarker to predict the risk of future cardiovascular events [27].

Researchers C. Donger et al. assumed that IL-10 gene polymorphism at $1082 \mathrm{~A}$ position may be associated with a liability to coronary artery disease. However, based on the results of the study, the researchers arrived at conclusion that IL-10 gene polymorphism is not associated with an increased risk of myocardial infarction [28].

The relationship of IL-10 gene polymorphism (-1082G/a, $-819 \mathrm{C} / \mathrm{T}, 592 \mathrm{C} / \mathrm{a}$ ) with restenosis after coronary stenting was studied by W. Koch et al. The study included 1850 patients with $\mathrm{CHD}$. The researchers found that the polymorphism is not associated with restenosis, death or AMI. Furthermore, they did not observe any relationship between polymorphism-specific haplotypes and adverse angiographic and clinical results [29].

Thus, the results of analysis of the above literature sources do not permit us to make a clear and unambiguous conclusion on the association of IL-10 gene polymorphism with cardiovascular disease. The inconsistency of research results may be due to ethnic differences in the population.

\section{Conclusions}

Analysis of the above literature allows us to make a conclusion that:

- first, the concentration of cytokines depends on the genetic characteristics of an individual; 
- secondly, cytokine gene polymorphism may be of importance in regard to the course of CHD.

Prospects for further research. The role of cytokine gene polymorphism in the development of acute myocardial infarction remains poorly studied, although it is of particular interest. So a special research should be conducted in order to identify the role of cytokine gene polymorphism for patients with acute myocardial infarction.

\section{References}

[1] Shafranskyi, V. V. (Ed) (2016) Shchorichna dopovid pro stan zdorovia naselennia, sanitarno-epidemichnu sytuatsiiu ta rezultaty diialnosti systemy okhorony zdorovia Ukrainy. 2015 rik [Annual report on the health status of the population, sanitary and epidemiological situation and results of operations of the health care system of Ukraine. 2015]. Kyiv [in Ukrainian].

[2] Shushliapin, O. I., Shelest, O. M., Borzova, O. Yu., \& Rynchak, P. I. (2015) Hostryi koronarnyi syndrom: porushennia imunnykh protsesiv, metabolizm lipidiv, bilkiv i predyktory zapalennia [Acute coronary syndrome: disorders of immune processes, metabolism of lipids, proteins, and predictors of inflammation]. Zdorovia Ukrainy, 2(39), 62-63 [in Ukrainian]

[3] Parkhomenko, A. N., Lutay, Ya. M., Irkin, O. I., Kozhukhov, S. N., Skarzhevsky, A. A., Dosenko, V. Ye., \& Moybenko, A. A. (2014) Kliniko-prognosticheskoe znachenie polimorfizma gena e'ndotelial'noj NO-sintetazy u bol'nykh s ostrymi koronarnymi sindromami [Clinical and Prognostic Value of Endothelial NO-Synthetase Gene Polymorphism in Patients with Acute Coronary Syndromes]. Medicina neotlozhnyh sostoyanij, 3(58), 45-54 [in Russian].

[4] Podolskaya, A. A., Maykova, E. V., Sharafetdinova, L. M. \& Kravtsova, O. A. (2014) Polimorfizm genov provospalitel'nykh citokinov v associacii s riskom razvitiya ostrogo infarkta miokarda [Polymorphism of genes of pro -inflammatory cytokines in association with risk of acute myocardial infarction]. Vestnik sovremennoj klinicheskoj mediciny, 7(2), 147-150 [in Russian].

[5] Orho-Melander, M. (2016) Genetika ishemicheskoj bolezni serdca: put' k e'tiologicheskim mekhanizmam, novym mishenyam terapii i bolee personificirovannoj profilaktike [Genetics of coronary heart disease: towards causal mechanisms, novel drug targets and more personalized prevention]. Kardiologiya: novosti, mneniya, obuchenie, 3, 15-28 [in Russian]. doi: 10.1111/joim.12407.

[6] Panchenko, E. A., Nevzorova, V. A., Belov, P. S., \& Isaeva, M. P. (2014) Polimorfizm genov matriksnykh metalloproteinaz 2 i 9 u pacientov pri infarkte miokarda i metabolicheskom sindrome [Polymorphism of matrix metalloproteinases 2 and 9 genes in patients with myocardial infarction combained with metabolic cyndrome]. Fundamental'nye issledovaniya, 10, 1964-1970 [in Russian].

[7] Chu, H., Yang, J., Mi, Sh., Bhuyan, S. S., Li, J., Zhong, L., et al. (2012) Tumor necrosis factor-alpha G-308 A polymorphism and risk of coronary heart disease and myocardial infarction: A case-control study and meta-analysis. Journal of Cardiovascular Disease Research, 3(2), 84-90. doi:10.4103/0975-3583.95359.

[8] Toutouzas, K., Klettas, D., Anousakis-Vlachochristou, N., Melidis, K., Azilazian, Z., Asimomiti, M., et al. (2017). The -174 G>C Interleukin-6 Gene Polymorphism is Associated with Angiographic Progression of Coronary Artery Disease over a 4-Year Period. Hellenic Journal of Cardiology, 58(1), 80-86. doi:10.1016/j.hjc.2017.02.002.

[9] Paleev, F. N., Belokopytova, I. S., Minchenko, B. I., \& Moskalec, O. V. (2011). Rol' citokinov v patogeneze ishemicheskoj bolezni serdca [The role of cytokines in the pathogenesis of coronary heart disease]. Kreativnaya kardiologiya, 1, 75-80 [in Russian].

[10] Ridker, P. M., Rifai, N., Stampfer, M. J., \& Hennekens, C. H. (2000). Plasma Concentration of Interleukin- 6 and the Risk of Future Myocardial Infarction Among Apparently Healthy Men. Circulation, 101(15), 1767-1772. doi:10.1161/01.cir.101.15.1767

[11] Gabriel, A. S., Ahnve, S., Wretlind, B., \& Martinsson, A. (2000). IL-6 and $\mathrm{IL}-1$ receptor antagonist in stable angina pectoris and relation of IL-6 to clinical findings in acute myocardial infarction. Journal of Internal Medicine, 248(1), 61-66. doi:10.1046/j.1365-2796.2000.00701.x.

[12] Aker, S., Bantis, C., Reis, P., Kuhr, N., Schwandt, C., Grabensee, B., et al. (2009). Influence of interleukin-6 G-174C gene polymorphism on coronary artery disease, cardiovascular complications and mortality in dialysis patients. Nephrology Dialysis Transplantation, 24(9), 2847-2851. doi:10.1093/ndt/gfp141.

[13] Sie, M. P., Mattace-Raso, F. U., Uitterlinden, A. G., Arp, P. P., Hofman, A Pols, H. A., et al. (2008) The interleukin-6-174 G/C promoter polymorphism and arterial stiffness; the Rotterdam Study. Vasc Health Risk Manag, 4(4), 863-9.

[14] Shevchenko, A. V., Golovanova, O. V., Konenkov, V. I., Voevoda, M. I., Maximov, V. N., \& Tolkacheva, O. M. (2014). Analiz vzaimosvyazi polimorfizma gena IL6 (-174 G/C) i klassicheskikh faktorov riska u pacientov s ostrym infarktom miokarda v anamneze [Analysis of correlation between il6 gene polymorphism $(-174 \mathrm{~g} / \mathrm{c})$ and classic risk factors in patients with previous myocardial infarctions]. Medicinskaya immunologiya, 11(6), 557. doi:10.15789/1563-0625-2009-6-557-566.

[15] Sprague, A. H., \& Khalil, R. A. (2009). Inflammatory cytokines in vascular dysfunction and vascular disease. Biochemical Pharmacology, 78(6), 539-552. doi:10.1016/j.bcp.2009.04.029.

[16] Willerson, J. T. (2002). Systemic and local inflammation in patients with unstable atherosclerotic plaques. Progress in Cardiovascular Diseases, 44(6), 469-478. doi:10.1053/pcad.2002.123782.

[17] Hajeer, A. H., \& Hutchinson, I. V. (2001). Influence of TNFa gene polymorphisms on TNFa production and disease. Human Immunology, 62(11) 1191-1199. doi:10.1016/s0198-8859(01)00322-6.

[18] Hollegaard, M. V., \& Bidwell, J. L. (2006). Cytokine gene polymorphism in human disease: on-line databases, Supplement 3. Genes and Immunity, 7(4), 269-276. doi:10.1038/sj.gene.6364301.

[19] Antonicelli, R., Olivieri, F., Cavallone, L., Spazzafumo, L., Bonafè, M., Marchegiani, F., et al. (2005). Tumor necrosis factor-alpha gene -308 $\mathrm{G}>$ A polymorphism is associated with ST-elevation myocardial infarction and with high plasma levels of biochemical ischemia markers. Coronary Artery Disease, 16(8), 489-493.

[20] Appoloni, O., Dupont, E., Vandercruys, M., Andrien, M., Duchateau, J., \& Vincent, J. (2004). Association Between the TNF-2 Allele and a Better Survival in Cardiogenic Shock. Chest, 125(6), 2232-2237. doi:10.1378/chest.125.6.2232.

[21] Wang, X. L., \& Oosterhof, J. (2000). Tumour necrosis factor a G-308A polymorphism and risk for coronary artery disease. Clinical Science, 98(4), 435. doi:10.1042/cs19990318.

[22] Keso, T., Perola, M., Laippala, P., Ilveskoski, E., Kunnas, T., Mikkelsson, J., et al. (2001). Polymorphisms within the tumor necrosis factor locus and prevalence of coronary artery disease in middle-aged men. Atherosclerosis, 154(3), 691-697. doi:10.1016/s0021-9150(00)00602-x.

[23] Sabat, R., Grütz, G., Warszawska, K., Kirsch, S., Witte, E., Wolk, K., \& Geginat, J. (2010). Biology of interleukin-10. Cytokine \& Growth Factor Reviews, 21(5), 331-344. doi:10.1016/j.cytogfr.2010.09.002.

[24] Karaca, E., Kayikcioglu, M., Onay, H., Gunduz, C., \& Ozkinay, F. (2011). The effect of interleukin-10 gene promoter polymorphisms on early-onset coronary artery disease. Anadolu Kardiyoloji Dergisi/The Anatolian Journal of Cardiology, 11(4), 285-289. doi:10.5152/akd.2011.077.

[25] Chao, L., Fei, J., \& Lei, H. (2014). A meta-analysis of interleukin-10-1082 promoter genetic polymorphism associated with atherosclerotic risk. Neurology India, 62(2), 130. doi:10.4103/0028-3886.132323.

[26] Trompet, S., Pons, D., Craen, A. J., Slagboom, P., Shepherd, J., Blauw, G. J., et al. (2007). Genetic Variation in the Interleukin-10 Gene Promoter and Risk of Coronary and Cerebrovascular Events: The PROSPER Study. Annals of the New York Academy of Sciences, 1100(1), 189-198. doi:10.1196/annals.1395.018.

[27] Malarstig, A., Eriksson, P., Hamsten, A., Lindahl, B., Wallentin, L., \& Siegbahn, A. (2008). Raised interleukin-10 is an indicator of poor outcome and enhanced systemic inflammation in patients with acute coronary syndrome. Heart, 94(6), 724-729. doi:10.1136/hrt.2007.119271.

[28] Donger, C., Georges, J., Nicaud, V., Morrison, C., Evans, A., Kee, F., et al (2001). New polymorphisms in the interleukin-10 gene - relationships to myocardial infarction. European Journal of Clinical Investigation, 31(1), 9-15. doi:10.1046/j.1365-2362.2001.00754.x.

[29] Koch, W. Tiroch, K., Beckerath, N. V., Schömig, A., \& Kastrati, A. (2003) Tumor necrosis factor-a, lymphotoxin- $\alpha$, and interleukin-10 gene polymorphisms and restenosis after coronary artery stenting. Cytokine, 24(4), 161-171. doi:10.1016/j.cyto.2003.08.004.

\section{Information about author:}

Sid' Ye. V., MD, PhD, Assistant, Department of Emergency

Medical Service, State Institute "Zaporizhzhia Medical Academy of Postgraduate Education of Ministry of Health of Ukraine".

\section{Відомості про автора:}

Сідь $€$. В., канд. меА. наук, асистент каф. медицини невідкладних станів, АЗ «Запорізька меАична академія післядипломної освіти М03 України".

\section{Сведения об авторе:}

Сидь Е. В., канА. меА. наук, ассистент каф. медицины неотложных состояний, ГУ «Запорожская медицинская академия последипломного образования МЗ Украины".

Конфлікт інтересів: віАсутній.

Conflicts of Interest: author has no conflict of interest to declare.

Надійшло Ао редакції / Received: 06.04.2017

Після Аоопрацювання / Revised: 12 .04.2017

Прийнято Ао Аруку / Accepted: 01.06.2017 